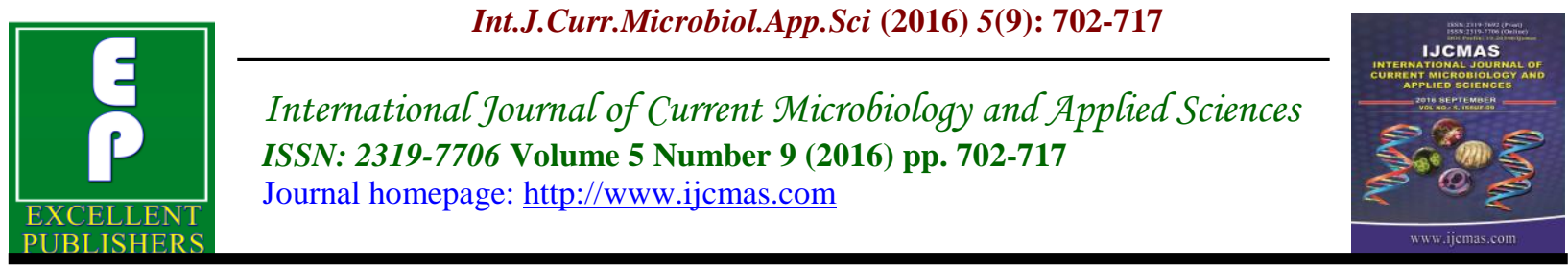

Original Research Article

http://dx.doi.org/10.20546/ijcmas.2016.509.081

\title{
A Study of Prevalence of Dermatophytosis in and around Guntur District, Andhra Pradesh, South India
}

\author{
Uma Penmetcha*, Ramesh Babu Myneni, Padmaja Yarlagadda and \\ Susmitha Simgamsetty
}

Department of Microbiology, NRI Medical College \& General Hospital, Chinakakani, Mangalagiri Mandal, Guntur District, Andhra Pradesh, India

*Corresponding author

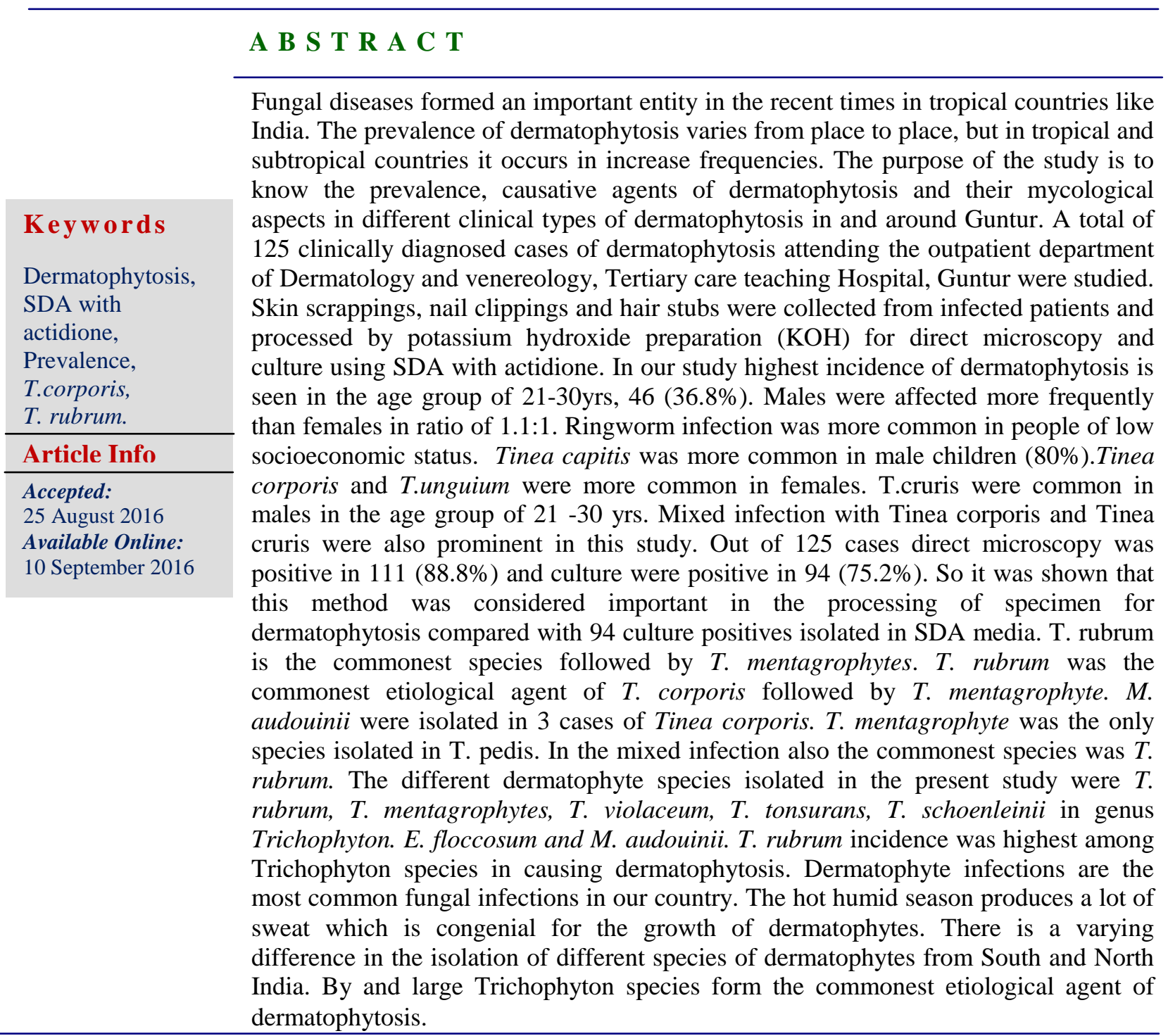




\section{Introduction}

Cutaneous infections are common diseases encountered in tropical countries, of which dermatophytosis are of particular concern in developing countries. This infection is prevalent in all age groups of both the sexes in our country and they seek physician advice mainly for the cosmetic reason. Dermatophytosis constitutes 16 to $75 \%$ of all mycological infections. It is commonly acquired due to hot humid climatic condition of our country. Overcrowding, low socioeconomic status, unhygienic living conditions, outdoor work, increased physical activity and excessive sweating predisposes to ring worm infection.

The Dermatophytes are a group of closely related fungi that have the capacity to invade the keratinized tissue (skin, hair, and nail) of humans and other animals to produce an infection, dermatophytosis, commonly referred to as ringworm. Infection is generally cutaneous and restricted to the nonliving cornified layers because of the inability of the fungi to penetrate the deeper tissues or organs of immunocompetent hosts. Reaction to a dermatophyte infection may range from mild to severe as a consequence of the hosts reactions to the metabolic products of the fungus, the virulence of the infecting strains or species, the anatomical location of the infection, and local environmental factors (Weitzman et al., 1995).

Emmons (1934) has classified dermatophytes broadly into three genera. Trichophyton, Microsporum and Epidermophyton. There were numerous reports of the prevalence of dermatophytosis in different parts of India. It is with this background the present study was undertaken to know the prevalence, causative agents, predisposing factors in dermatophytosis and their mycological aspects in different clinical types of dermatophytosis in around Guntur.

\section{Material and Methods}

The study was undertaken with a view to isolate and identify various species of the dermatophytes from the clinical specimens such as skin scrapping, nail clipping and hair stubs from 125 clinically suspected cases of dermatophytosis attending the outpatient department of Dermatology, Tertiary care teaching Hospital, Guntur, over a period of one year.

A detailed clinical history was taken from all patients after obtaining informed consent. It included age, sex, socioeconomic status, occupation, site of infection, duration of disease, history of similar illness in family, history of recurrence, lifestyle and history of associated diseases were elicited and recorded in proforma. Patients on antifungal treatment and non - dermatophyte fungal infections were excluded from the study. Depending on the clinical types of dermatophytosis and site of lesions, skin scrapings, nail clippings along with subungual debris and infected hair stubs were collected. The site of lesion were cleaned with $70 \%$ alcohol, allowed to dry then samples were collected using sterile scalpel blade in a sterile black paper folds and labelled with details of the patient. The collected samples were transported to the laboratory immediately without any delay for microscopic examination \& culture.

Direct microscopic examination of the scraping placed on a microscopic slide with one or two drops of $20 \%$ potassium hydroxide $\&$ a cover slip was applied. The sample was warmed by passing the slide several times over a flame of Bunsen burner $\&$ examined under microscope. A sample like nail clipping along with subungual debris was placed on a microscopic slide with few drops of $40 \% \mathrm{KOH}$ and a cover 
slip was applied. The preparation was examined after 6 hours, so that the nails get dissolved in $\mathrm{KOH} \&$ hyphae and / arthroconidia become clearly visible when examined under low (x10) and high (x40) power objective (Koneman et al., 1997).

The culture was performed in two different sets of antibiotic incorporated Sabouraud dextrose agar (SDA) media, one with chloramphenicol $50 \mathrm{mg} / \mathrm{l}$ and the other with cycloheximide $500 \mathrm{mg} / \mathrm{L}$ and in addition to chloramphenicol and gentamicin (Emmons et al., 1977)

The cultures were incubated at $25^{\circ} \mathrm{c}$ for one to four weeks and checked twice in a week for any growth. In case of positive cultures identification of the causative agents was performed based on macroscopic \& microscopic examination of culture isolates which include gross morphology of the fungal colony (texture, color, surface and reverse pigment, topography), rate of colony growth. Microscopic examination was done using Lactophenol cotton blue preparation. Fungal conidia (type of macroconidia, shape and size of microconidia) and accessory structures were studied using slide culture method. Special test like hair perforation test, urease production and slide culture were performed whenever necessary by standard technique (Forbes et al., 2002). In absence of growth even after four weeks, the culture was declared negative.

\section{Results and Discussion}

Out of 125 samples collected, skin scrapings formed $104(83.2 \%)$ samples, nail clippings were $16(12.8 \%)$ and hair stubs 5(4\%) (Table-1). Sex wise incidence of cases showed male predominance. The incidence in males was $66(52.8 \%)$ and females 59 (47.2\%). The male to female ratio was $1.1: 1$ (Table-2). Highest incidence was seen in the age group of 21-30yrs 46(36.8\%) followed by $11-20 y r s$ age group and $31-40 y r s$ age which had an incidence of 23 (18.4\%) each. Age group of 41-50yrs had an incidence of 15 (12\%), 51-60yrs age group 12 (19.6\%) and $0-10$ yrs age group has least incidence $6(4.8 \%$ ) (Table-3). Categorisation of cases by socioeconomic status revealed that the incidence of ringworm infection was more in people of low socioeconomic status $85(68 \%)$ followed by $36(28.8 \%)$ in middle socioeconomic status, and in high socioeconomic status it was least common 4 $(3.2 \%)$ (Table-4). In this study $42 \%$ of patients which include both male and female cases were farmers in the age group of 21-40 yrs, who were in contact with soil as a part of their occupation. In our study, Tinea capitis was more common in male children $(80 \%)$ and in age group of $0-10 \mathrm{yrs}(80 \%)$. Tinea corporis was found to be more common in females $(60 \%)$ and in age group of $21-30 y r s(41.8 \%)$. Tinea cruris is more common in males $(76 \%)$ and in age group of $21-30 y r s$ (38.46\%). Tinea unguium is common in females $(56.25 \%)$ and in age group of 21-30yrs (37.21\%). There was one female case of T.pedis in age group of 21 $30 \mathrm{yrs}$ and 2 cases of $T$. manuum, one was a male, one was a female patient in age group of 21 -30 yrs. Tinea barbae was seen in 3 males in age group of 21-30yrs. Mixed infection with T.corporis and T. cruris was also prominent in this study. Of the 30 cases of mixed infection 19 were males $(63.34 \%)$ and 11 were females $(36.67 \%)$. The predominant age group of mixed infection was 21-30 yrs and 41-50 yrs each of $(22.5 \%)$ incidence, (Table-5).

Out of 125 cases, direct microscopy was positive in $111(88.8 \%)$ cases and culture positive in $93(75.2 \%)$ cases. 85 cases $(68 \%)$ were both $\mathrm{KOH}$ positive and culture positive. 20 cases (16\%) were $\mathrm{KOH}$ positive but culture negative. Whereas 8 cases 
(6.4\%) were $\mathrm{KOH}$ negative but culture positive. $12(9.6 \%)$ were both $\mathrm{KOH}$ and culture negative, (Table- 6). In our study, $T$. rubrum was the commonest pathogenic species isolated $32(37.64 \%)$ followed by T.mentagrophytes 26(30.58\%). T. violaceum, $T$. tonsurans and $T$. verrucosum with an incidence of $7.05 \%$ (each 6 isolates). There were two isolates of T.schoenleinii $(2.35 \%)$, Epidermophyton floccosum in 4 (4.75\%) and $M$. audouinii in $3(3.53 \%)$ were isolated (Table- 7). Dermatophytes isolated from different clinical types (Table-8) showed that $T$. rubrum (16) was the most common pathogenic fungi in clinical type $T$. corporis followed by T.mentagrophytes (13), T.tonsurans, T.verrucosum were isolated in 3 cases each. T. violaceum and $T$. schoenleinii 2 cases each, of T.corporis, $M$. audouinii in 3 cases, E. floccosum in one case of $T$. corporis 55 (44\%). In 16 cases (12.8\%) of $T$. unguium, there were only 2 isolates of $T$. rubrum. In $T$. cruris 13 (10.4\%) different dermatophyte species isolated were T. rubrum (3). T.mentagrophytes (2), T. violaceum (1),T. tonsurans (1), Epidermophyton (1). In $5(4 \%)$ cases of $T$. capitis 3 isolates were $T$. violaceum, $T$. tonsurans one, $T$. verrucosum (1). T.mentagrophytes was the only isolates of $T$. pedis. Among the two cases (1.6\%) of T. manuum, T. rubrum was isolated from one case. Out of 3 cases $(2.4 \%)$ of $T$. barbae, T. rubrum was isolated in 2 cases and T.mentagrophytes in one case. Mixed infection ( $T$. corporis and $T$. cruris) was noticed in 30 cases $(24.8 \%)$. The common species isolated were $T$. rubrum (9) followed by T.mentagrophytes (8), T. tonsurans (1), $T$. verrucosum (2) and E. floccosum was isolated in 2 cases.

Dermatophytosis is the most common fungal infection of human and is usually referred to as tinea (Latin for worm) or ring worm. The infection is characterised by another latin name to designate the area of the body involved T. corporis, T cruris, T.capitis, $T$. barbae, T.unguium and T. manuum. These fungi breakdown and utilize keratin as a source of nitrogen. The genus Trichophyton is capable of invading hair, skin $\&$ nail. The Genus Microsporum involve skin \& hair and Genus Epidermophyton involve skin and nails.

In the present study, 125 clinically diagnosed cases of dermatophytosis attending Dermatology department were taken. Highest incidence was seen in the age group of $21-30 \mathrm{yrs}(36.8 \%)$ followed by 11 $20 y r s$ and $31-40 y r s$ age group (18.4\%). Males $(52.8 \%)$ are affected more than females $(47.2 \%)$. Male to female ratio is 1.1:1 (Table 2,3). Similar findings were reported by Bose et al.,2013, Gupta et al., 2014, Ramaraj V et al.,2016. The increase incidence in males may be due to outdoor work, increase physical activity in hot humid climate, excessive sweating, poor hygienic conditions and wearing of occlusive clothing, predisposes to ring worm infection. In our study, dermatophyte infection was more common in people of low socioeconomic status 85 (68\%). Most of the male and female cases under this category were daily wage labourers and farmers who work outdoor and are more exposed to soil as a part of their occupation, which in turn predisposes to dermatophyte infection. Similar finding were reported by Ranganathan et al., 1995; Poluri et al., 2015; a high incidence of dermatophyte infection was observed in low socioeconomic group of people $35 \%$ and $67.74 \%$ in their study.

In the present study, Tinea capitis was more common in male children 0-10yrs (80\%). Tinea corporis $33(60 \%)$ in females and in the age group of 21-30yrs 23 (41.8\%) and 31 - 40yrs $13(23.6 \%)$ was commonly seen around waistline of females who wear sarees and work outdoor in our study. T. unguium 
was found to be more common in females 9(56.25\%). Tinea cruris was more common in males $10(76 \%)$. However some workers found Tinea cruris as the commonest clinical type, Damle et al., 1981 and Singh et al., 1981. The commonest age group for T.corporis and T. cruris was $21-30 \mathrm{yrs}$ in both males and females. Our findings is in accordance with Poluri et al., 2015; Sudha et al., 2016 and Kanwar et al., 2001 study. All Tinea capitis cases were in the age group of 0-10 yrs in our study. This corresponds to the study by Sudha et al., 2003 and Philpo, 1997 in which he reported that Tinea capitis was a disease of children. It is said that pubertal changes in harmones results in acidic sebaceous gland secretions which is responsible for decrease in incidence of Tinea capitis in adults. T. unguium was found to be more common in females in our study may be due to more exposure to water as part of their daily work. In a study conducted by Gupta et al., 2014 and Reena Ray Ghosh et al., 2014, Tinea unguium was the commonest clinical type observed (52\%) and $(74.58 \%)$ followed by Tinea corporis $(25 \%) \&(8.65 \%)$. T. cruris was more common in males than females in our study (76\%) which corresponds to Sudha et al., 2016 and Kanwar et al., 2001, study. Who also showed the incidence of $T$. cruris common in males $20.8 \%, 15.6 \%$ respectively.

Table.1 Categorical distribution of clinical samples

\begin{tabular}{|c|c|c|}
\hline Type of Specimens & Number of cases & Percentages \\
\hline Skin scrapings & 104 & 83.2 \\
\hline Nail clippings & 16 & 12.8 \\
\hline Hair stubs & 5 & 4 \\
\hline Total & 125 & 100 \\
\hline
\end{tabular}

Table.2 Age wise distribution of cases

\begin{tabular}{|l|c|c|}
\hline Age in years & Number of cases & Percentages \\
\hline $\mathbf{0 - 1 0}$ & 6 & 4.87 \\
\hline $\mathbf{1 1 - 2 0}$ & 23 & 18.4 \\
\hline $\mathbf{2 1 - 3 0}$ & 46 & 36.8 \\
\hline $\mathbf{3 1 - 4 0}$ & 23 & 18.4 \\
\hline $\mathbf{4 1 - 5 0}$ & 15 & 12 \\
\hline $\mathbf{5 1 - 6 0}$ & 12 & 9.6 \\
\hline Total & 125 & 100 \\
\hline
\end{tabular}

Table.3 Distribution of cases by socioeconomic status wise

\begin{tabular}{|c|c|c|c|}
\hline $\begin{array}{c}\text { Low socioeconomic } \\
\text { status }\end{array}$ & $\begin{array}{c}\text { Middle } \\
\text { socioeconomic status }\end{array}$ & $\begin{array}{c}\text { High socioeconomic } \\
\text { status }\end{array}$ & Total \\
\hline Number of cases & Number of cases & Number of cases & \\
\hline $85(68 \%)$ & $36(28.8 \%)$ & $4(3.2 \%)$ & 125 \\
\hline
\end{tabular}


Fig.1 Categorical distribution of clinical samples

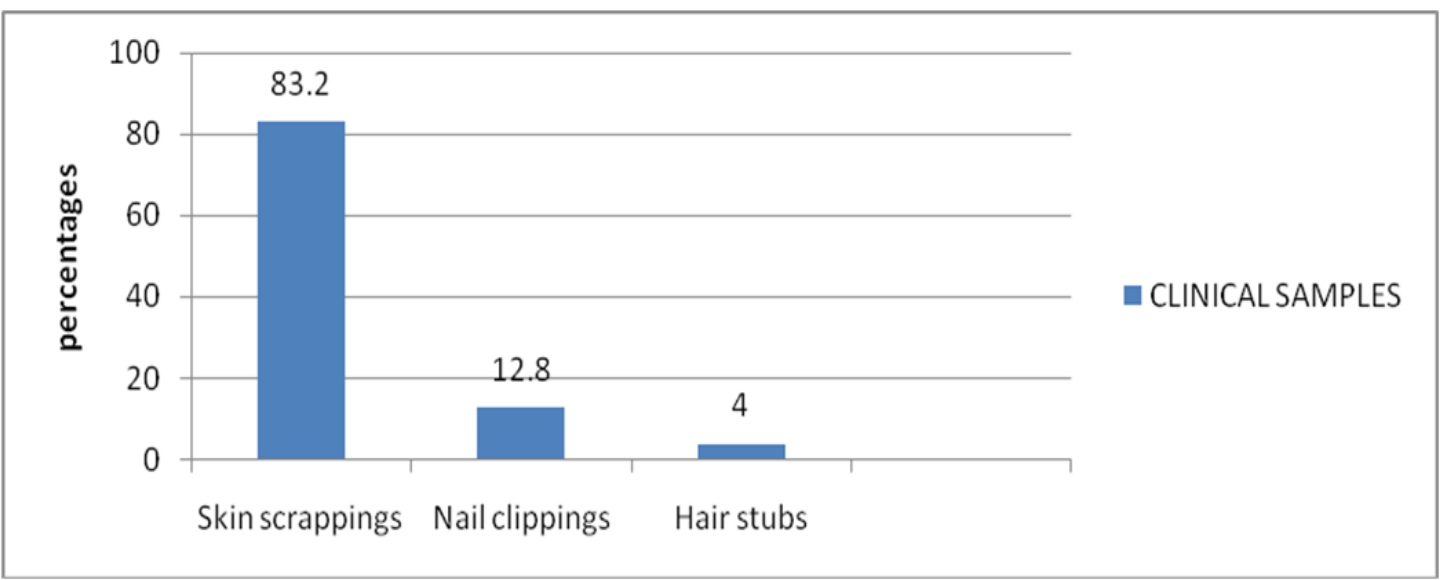

Fig.2 Sex wise distribution of cases

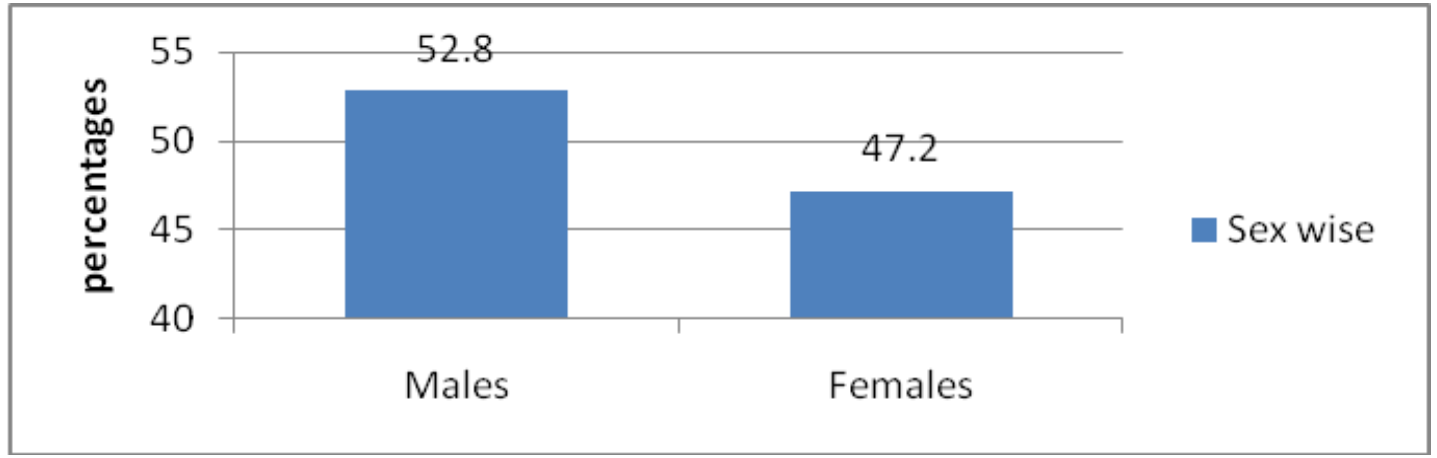

Fig.3 Age wise distribution of cases

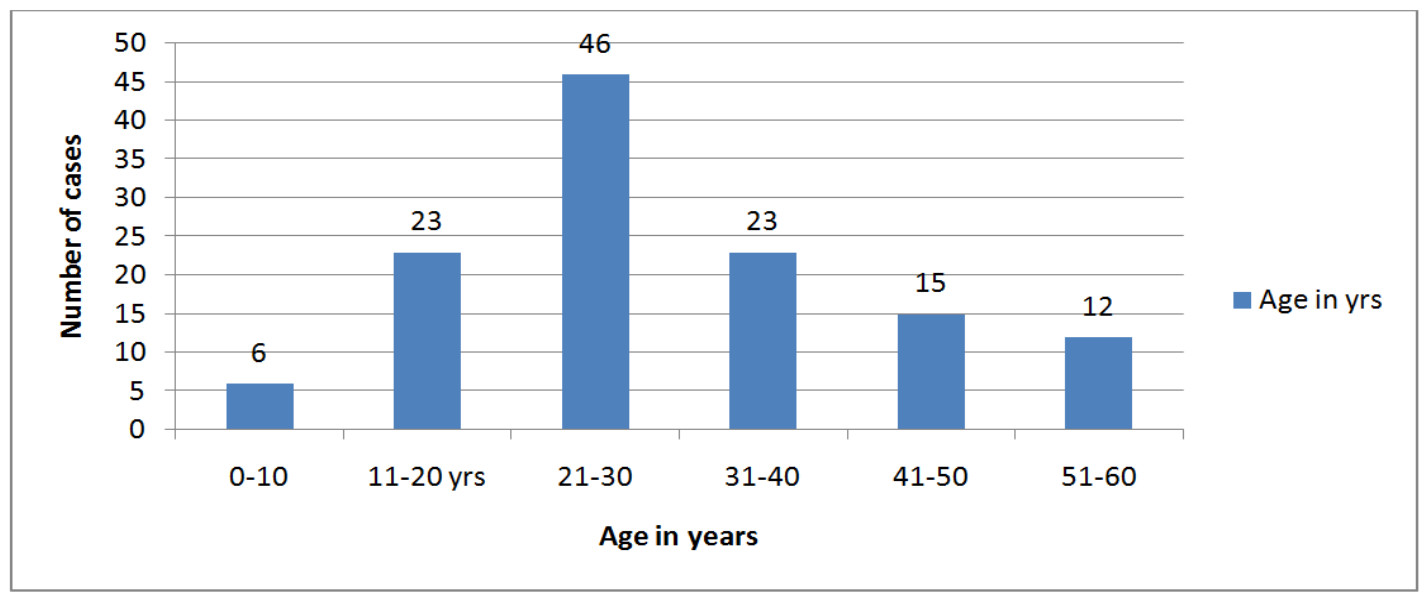


Int.J.Curr.Microbiol.App.Sci (2016) 5(9): 702-717

Table.4 Correlation of clinical types age and sex wise

\begin{tabular}{|c|c|c|c|c|c|c|c|c|c|c|}
\hline \multirow[t]{2}{*}{ S.No } & \multirow[t]{2}{*}{ Clinical types } & \multicolumn{6}{|c|}{ Age group in years } & \multicolumn{2}{|l|}{ Sex wise } & \multirow[t]{2}{*}{ Total } \\
\hline & & $0-10$ & $11-20$ & $21-30$ & $31-40$ & $41-50$ & $\begin{array}{l}51 \& \\
\text { above }\end{array}$ & Male & Female & \\
\hline 1. & T. corporis & $\begin{array}{l}2 \\
(3.6 \%)\end{array}$ & $8(14.5 \%)$ & $\begin{array}{l}23 \\
(41.8 \%)\end{array}$ & $\begin{array}{l}13 \\
(23.6 \%)\end{array}$ & $\begin{array}{l}6 \\
(10.9 \%)\end{array}$ & $3(5.4 \%)$ & $22(40 \%)$ & $33(60 \%)$ & $55(44 \%)$ \\
\hline 2. & T. cruris & - & $3(23 \%)$ & $\begin{array}{l}5 \\
(38.46 \%)\end{array}$ & $3(23.7 \%)$ & $1(7.6 \%)$ & $1(7.6 \%)$ & $10(76 \%)$ & $3(23 \%)$ & $13(10.4 \%)$ \\
\hline 3. & T. unguium & - & $\begin{array}{l}5 \\
(31.25 \%)\end{array}$ & $6(37.2 \%)$ & $2(12.5 \%)$ & $1(6.25 \%)$ & $\begin{array}{l}2 \\
(7.25 \%)\end{array}$ & $7(13.75 \%)$ & $\begin{array}{l}9 \\
(56.25 \%)\end{array}$ & $16(12.8 \%)$ \\
\hline 4. & T. capitis & $\begin{array}{l}4 \\
(80 \%)\end{array}$ & $1(20 \%)$ & - & - & - & - & $4(80 \%)$ & $1(20 \%)$ & $5(4 \%)$ \\
\hline 5. & T. pedis & - & - & $1(100 \%)$ & - & - & - & - & $1(100 \%)$ & $1(0.8 \%)$ \\
\hline 6. & T. тапиит & - & - & $2(100 \%)$ & - & - & - & $1(50 \%)$ & $1(50 \%)$ & $2(1.6 \%)$ \\
\hline 7. & T. barbae & - & - & $3(100 \%)$ & - & - & - & $3(100 \%)$ & & $3(2.4 \%)$ \\
\hline \multirow[t]{2}{*}{8.} & $\begin{array}{l}\text { Mixed type. } \\
\text { T.corporis } \\
+T . \text { cruris }\end{array}$ & - & $\begin{array}{l}6 \\
(19.35 \%)\end{array}$ & $7(22.5 \%)$ & $\begin{array}{l}5 \\
(16.12 \%)\end{array}$ & $7(22.5 \%$ & $7(22.5$ & $20(60.5 \%$ & $\begin{array}{l}11 \\
(35.48 \%\end{array}$ & $30(24.8 \%$ \\
\hline & Total & $\begin{array}{l}6 \\
(4.8 \%)\end{array}$ & $\begin{array}{l}23 \\
(18.4 \%)\end{array}$ & $\begin{array}{l}46 \\
(36.8 \%)\end{array}$ & $\begin{array}{l}23 \\
(18.4 \%)\end{array}$ & $15(12 \%)$ & $15(12 \%)$ & $\begin{array}{l}66 \\
(52.8 \%)\end{array}$ & $\begin{array}{l}59 \\
(47.2 \%)\end{array}$ & $125(100 \%$ \\
\hline
\end{tabular}


Table.5 Identification of Dermatophytes by Microscopy and culture wise among clinical types

\begin{tabular}{|l|l|l|l|l|l|l|l|l|}
\hline $\begin{array}{l}\text { S. } \\
\text { No }\end{array}$ & $\begin{array}{l}\text { Clinical } \\
\text { types }\end{array}$ & $\begin{array}{l}\text { Number } \\
\text { of cases }\end{array}$ & $\begin{array}{l}\text { Total } \\
\text { KOH } \\
\text { positive }\end{array}$ & $\begin{array}{l}\text { Total } \\
\text { culture } \\
\text { positive }\end{array}$ & $\begin{array}{l}\text { KOH } \\
\text { positive } \\
\text { culture } \\
\text { positive }\end{array}$ & $\begin{array}{l}\text { KOH } \\
\text { positive } \\
\text { culture } \\
\text { negative }\end{array}$ & $\begin{array}{l}\text { KOH } \\
\text { negative } \\
\text { Culture } \\
\text { positive }\end{array}$ & $\begin{array}{l}\text { KOH } \\
\text { Negative } \\
\text { Culture } \\
\text { Negative }\end{array}$ \\
\hline $\mathbf{1 .}$ & T. corporis & 55 & 51 & 43 & $\begin{array}{l}40 \\
(72.7 \%)\end{array}$ & $\begin{array}{l}10(18.19 \\
\%)\end{array}$ & $3(5.45 \%)$ & $2(3.63 \%)$ \\
\hline $\mathbf{2 .}$ & T.cruris & 13 & 13 & 11 & $\begin{array}{l}11 \\
(84.62 \%)\end{array}$ & $\begin{array}{l}2(15.38 \\
\%)\end{array}$ & - & - \\
\hline $\mathbf{3 .}$ & T. unguium & 16 & 6 & 2 & $1(6.25 \%$ & $\begin{array}{l}5(31.25 \\
\%)\end{array}$ & $1(6.25 \%)$ & $\begin{array}{l}9(56.25 \\
\%)\end{array}$ \\
\hline $\mathbf{4 .}$ & T.capitis & 5 & 5 & 5 & $4(80 \%)$ & - & $1(20 \%)$ & - \\
\hline $\mathbf{5 .}$ & T. pedis & 1 & 1 & 1 & - & - & 1 & - \\
\hline $\mathbf{6 .}$ & T. manuum & 2 & 2 & 2 & - & - & - & - \\
\hline $\mathbf{7 .}$ & T. barbae & 3 & 3 & 3 & 3 & - & - & - \\
\hline $\mathbf{8 .}$ & Mixed type & 30 & 30 & 27 & $24(80 \%)$ & $3(9.68 \%)$ & $2(6.45 \%)$ & $1(3.23 \%$ \\
\hline & Total & 125 & $111(88.8$ & $94(75.2$ & $85(68 \%)$ & $20(16 \%)$ & $8(6.4 \%)$ & $12(9.6 \%)$ \\
\hline & & $\%)$ & $\%)$ & & & & \\
\hline
\end{tabular}

Table.6 Incidence of dermatophytes species wise

\begin{tabular}{|l|l|c|}
\hline S. No. & $\begin{array}{l}\text { Dermatophyte } \\
\text { species }\end{array}$ & $\begin{array}{l}\text { Number of isolates / } \\
\text { percentages }\end{array}$ \\
\hline $\mathbf{1 .}$ & T. rubrum & $32(37.64 \%)$ \\
\hline $\mathbf{2 .}$ & T.mentagrophytes & $26(30.58 \%)$ \\
\hline $\mathbf{3 .}$ & T. violaceum & $6(7.06 \%)$ \\
\hline $\mathbf{4 .}$ & T. tonsurans & $6(7.06 \%)$ \\
\hline $\mathbf{5 .}$ & T. schoenleinii & $2(2.35 \%)$ \\
\hline $\mathbf{6 .}$ & T. verrucosum & $6(7.06 \%)$ \\
\hline $\mathbf{7 .}$ & M. audouinii & $3(3.53 \%)$ \\
\hline $\mathbf{8 .}$ & E.floccosum & $4(4.37 \%)$ \\
\hline & Total 125 cases & $85(100 \%)$ \\
\hline
\end{tabular}


Table.7 Dermatophytes isolated from different clinical types

\begin{tabular}{|c|c|c|c|c|c|c|c|c|c|c|}
\hline S.No. & Clinical types & Number & $\begin{array}{l}\text { T. } \\
\text { rubrum }\end{array}$ & T.mentagrophytes & $\begin{array}{l}T . \\
\text { violaceum }\end{array}$ & $\begin{array}{l}T . \\
\text { tonsurans }\end{array}$ & $\begin{array}{l}\text { T. } \\
\text { schoenleinii }\end{array}$ & $\begin{array}{l}T . \\
\text { verrucosum }\end{array}$ & M.audouinii & E.floccosum \\
\hline 1. & T. corporis & $55(44 \%)$ & 16 & 13 & 2 & 3 & 2 & 3 & 3 & 1 \\
\hline 2. & T. cruris & $\begin{array}{l}13 \\
(10.4 \%)\end{array}$ & 3 & 2 & 1 & 1 & - & - & - & 1 \\
\hline 3. & T. unguium & $\begin{array}{l}16 \\
(12.8 \%)\end{array}$ & 2 & - & - & - & - & - & - & - \\
\hline 4. & T. capitis & $5(4 \%)$ & - & - & 3 & 1 & - & 1 & - & - \\
\hline 5. & T.pedis & $1(0.8 \%)$ & - & 1 & - & - & - & - & - & - \\
\hline 6. & T.manuиm & $2(1.6 \%)$ & 1 & - & - & - & - & - & - & - \\
\hline 7. & T.barbae & $3(2.4 \%)$ & 2 & 1 & - & - & - & - & - & - \\
\hline \multirow[t]{2}{*}{8} & $\begin{array}{l}\text { Mixed type. } \\
\text { T.corporis+T.cruris }\end{array}$ & $\begin{array}{l}30 \\
(24.8 \%)\end{array}$ & 9 & 8 & - & 1 & - & 2 & - & 2 \\
\hline & Total cases & $\begin{array}{l}125 \\
(100 \%)\end{array}$ & $\begin{array}{l}32 \\
(37.64 \%)\end{array}$ & $26(30.58 \%)$ & $6(7.05 \%)$ & $6(7.05 \%)$ & $2(2.35 \%)$ & $6(7.05 \%)$ & $3(3.53 \%)$ & $4(4.75 \%)$ \\
\hline
\end{tabular}


Table.8 Reports of dermatophytosis in India

\begin{tabular}{|c|c|c|c|c|c|c|c|c|c|}
\hline \multirow[b]{2}{*}{ Author } & \multirow[b]{2}{*}{$\begin{array}{l}\text { Region, Year } \\
\text { of study, }\end{array}$} & \multirow[b]{2}{*}{$\begin{array}{l}\text { Commo } \\
\text { nest } \\
\text { clinical } \\
\text { type }\end{array}$} & \multicolumn{7}{|c|}{ Isolates with percentages if given } \\
\hline & & & $\begin{array}{l}T . \\
\text { rubrum }\end{array}$ & $\begin{array}{l}\text { T.menta } \\
\text { grophyt } \\
\text { es }\end{array}$ & $\begin{array}{l}T . \\
\text { violace } \\
\text { um }\end{array}$ & $\begin{array}{l}T . \\
\text { tonsurans }\end{array}$ & T. schoenleinii & $\begin{array}{l}\text { Epiderm } \\
\text { ophyton }\end{array}$ & Microsporum \\
\hline $\begin{array}{l}\text { Mathur } \\
\text { et al }\end{array}$ & $\begin{array}{l}\text { Central Nepal, } \\
2012\end{array}$ & $\begin{array}{l}\text { T.corpor } \\
\text { is }(47 \%)\end{array}$ & $25 \%$ & $8.8 \%$ & - & $25 \%$ & $\begin{array}{l}\text { T.verrucosum } \\
(30.6 \%)\end{array}$ & - & - \\
\hline Bose et al & $\begin{array}{l}\text { Maharashtra,20 } \\
13\end{array}$ & $\begin{array}{l}T . \\
\text { corporis } \\
(42 \%)\end{array}$ & $33.33 \%$ & $21.33 \%$ & - & - & - & $3.29 \%$ & $2.19 \%$ \\
\hline $\begin{array}{l}\text { Gupta et } \\
\text { al }\end{array}$ & $\begin{array}{l}\text { Central India, } \\
2014\end{array}$ & $\begin{array}{l}\text { T.ungui } \\
\text { um, } \\
(52 \%)\end{array}$ & $26.9 \%$ & $11.5 \%$ & - & $3.8 \%$ & $\begin{array}{l}\text { T.verrucosum } \\
(5.7 \%)\end{array}$ & $1.9 \%$ & - \\
\hline $\begin{array}{l}\text { Reena } \\
\text { Roy } \\
\text { Ghosh et } \\
\text { al }\end{array}$ & $\begin{array}{l}\text { West Bengal, } \\
2014\end{array}$ & $\begin{array}{l}\text { T. } \\
\text { unguium } \\
74.58 \%\end{array}$ & $22.2 \%$ & $21.16 \%$ & $2.11 \%$ & $\begin{array}{l}\text { T.saudanen } \\
\text { se } 4.76 \%\end{array}$ & $\begin{array}{l}\text { T.schoenleinii } \\
(6.34 \%)\end{array}$ & $4.23 \%$ & $13.7 \%$ \\
\hline $\begin{array}{l}\text { Poluri et } \\
\text { al }\end{array}$ & $\begin{array}{l}\text { Nalgonda,Telan } \\
\text { gana, } 2015\end{array}$ & $\begin{array}{l}T . \\
\text { corporis } \\
38.71 \%\end{array}$ & $58.06 \%$ & $22.58 \%$ & $6.45 \%$ & $3.22 \%$ & $3.22 \%$ & $6.45 \%$ & - \\
\hline $\begin{array}{l}\text { Ramraj } \\
\text { V et al }\end{array}$ & $\begin{array}{l}\text { Tamilnadu, } \\
2016\end{array}$ & $\begin{array}{l}T . \\
\text { corporis } \\
63.27 \%\end{array}$ & $48.95 \%$ & $44.75 \%$ & - & $3.05 \%$ & - & $0.70 \%$ & $2.1 \%$ \\
\hline $\begin{array}{l}\text { Present } \\
\text { study }\end{array}$ & $\begin{array}{l}\text { Guntur, Andhra } \\
\text { Pradesh }\end{array}$ & $\begin{array}{l}\text { T.corpor } \\
\text { is }(44 \%)\end{array}$ & $37.64 \%$ & $30.58 \%$ & $7.05 \%$ & $7.05 \%$ & $2.35 \%$ & 4.75 & $3.53 \%$ \\
\hline
\end{tabular}


Fig.4 Incidence of dermatophytes species wise

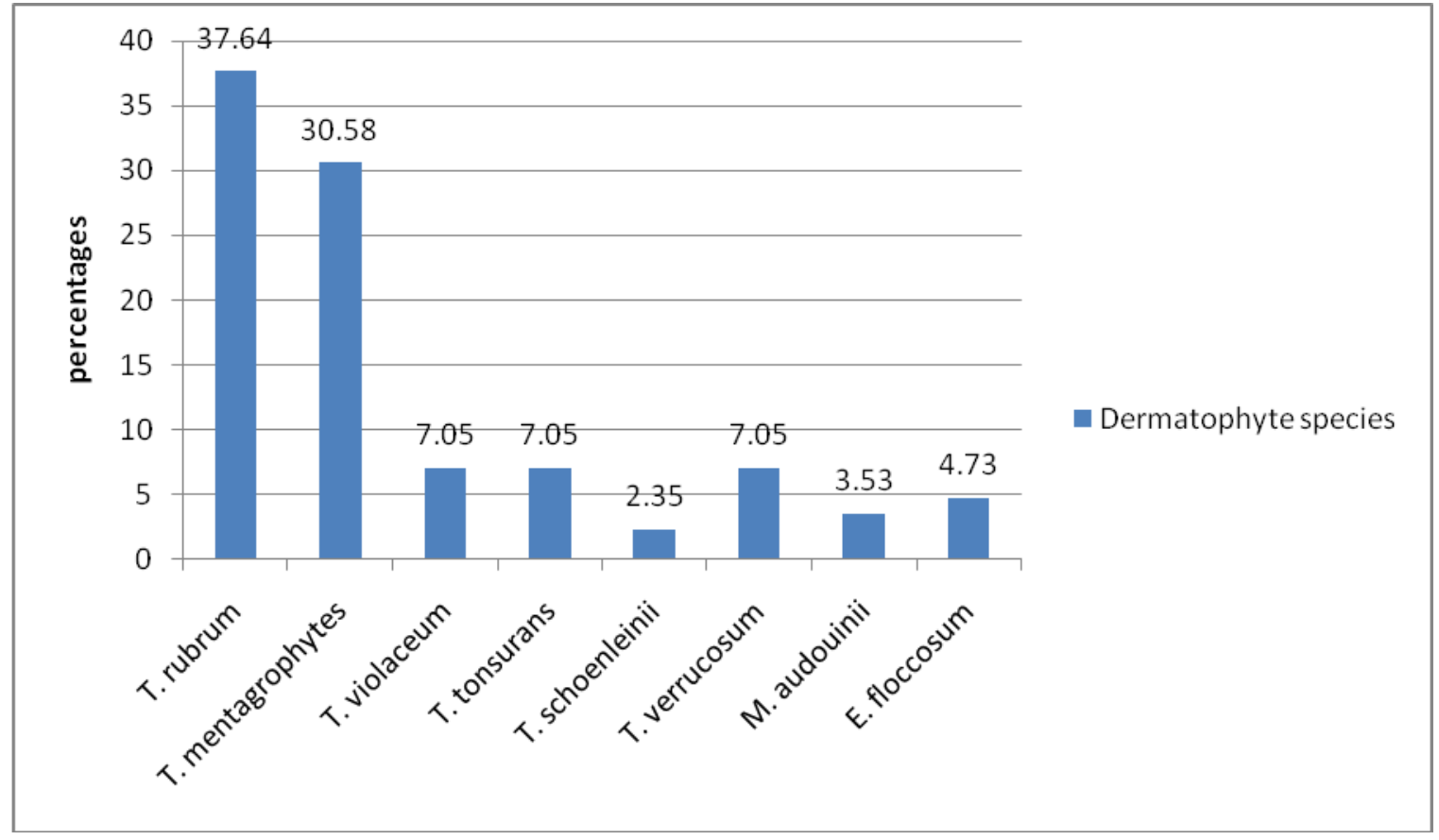

Images of dermatophytosis - Clinical cases, $\mathrm{KOH}$ mount and clinical isolates with LPCB mounts

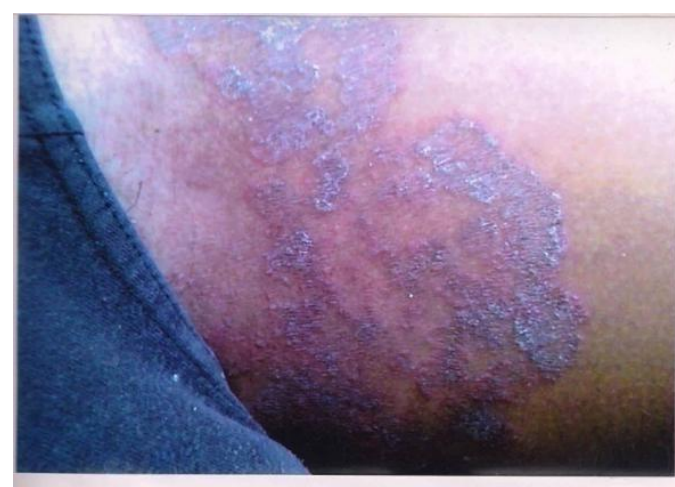

Tinea corporis

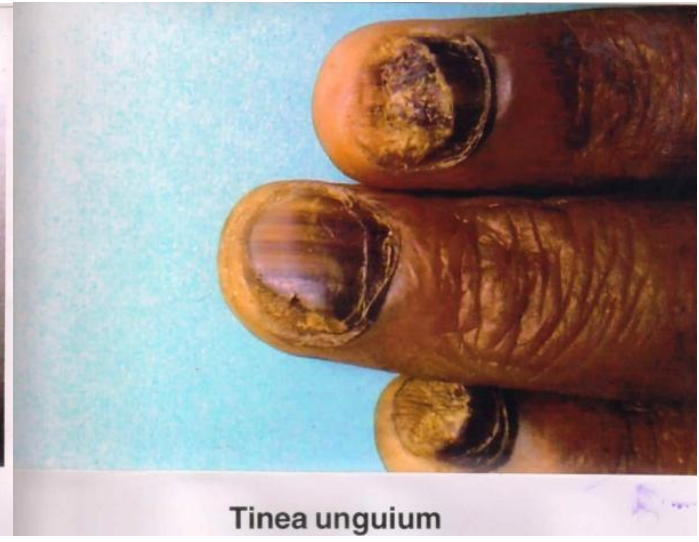




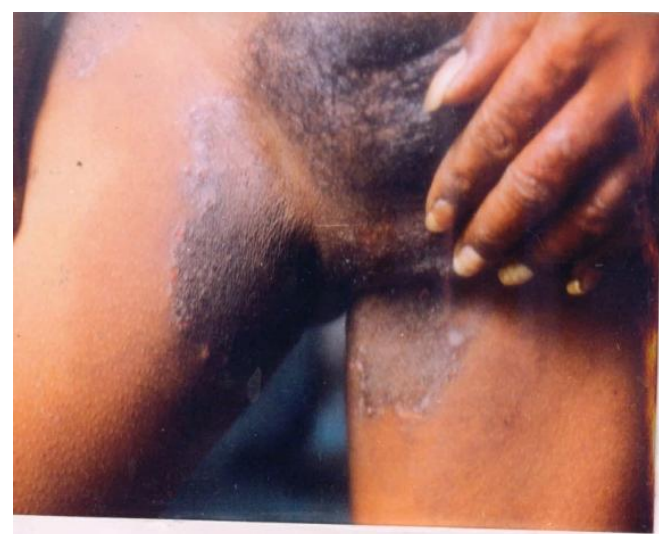

Tinea cruris
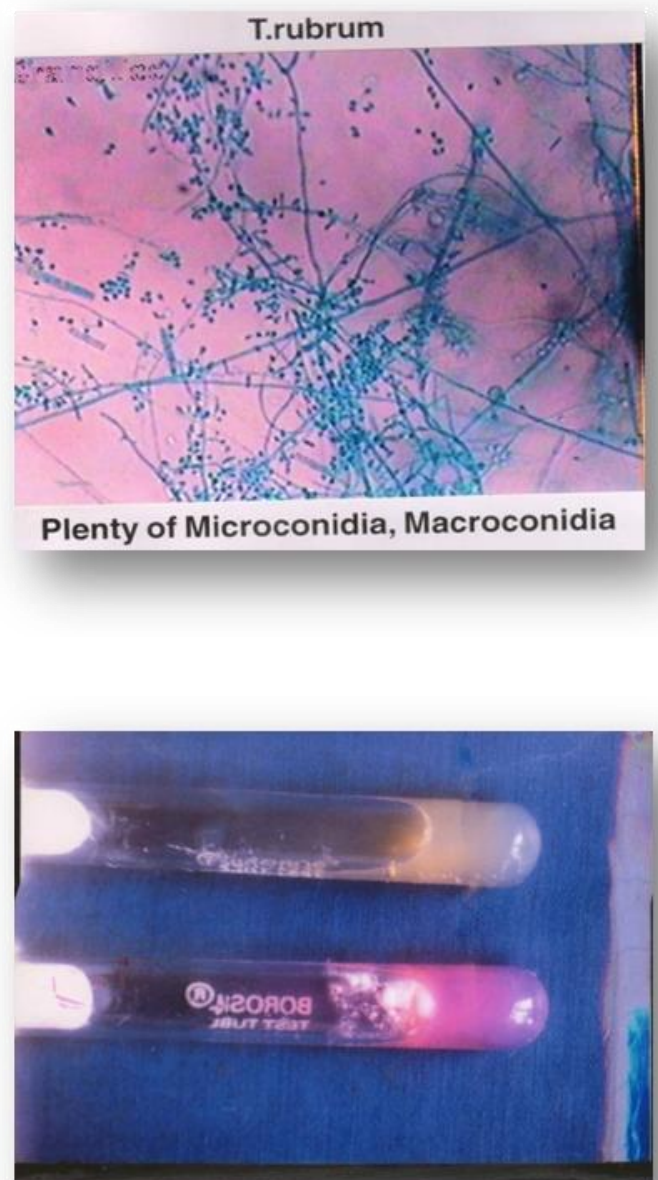

Urease test

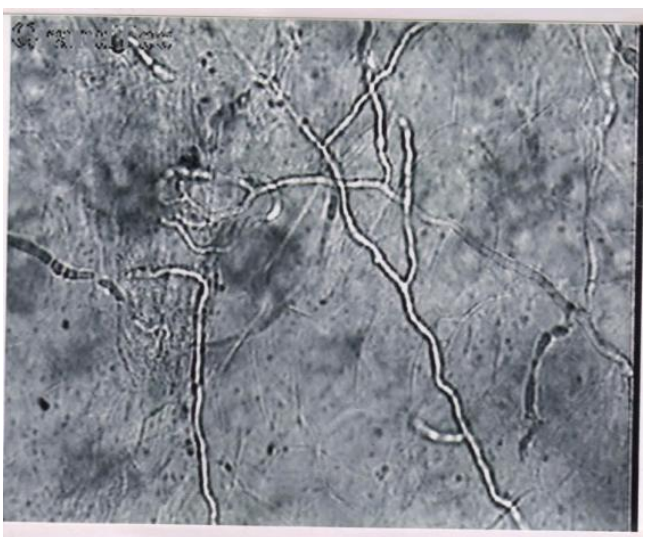

KOH Preparation

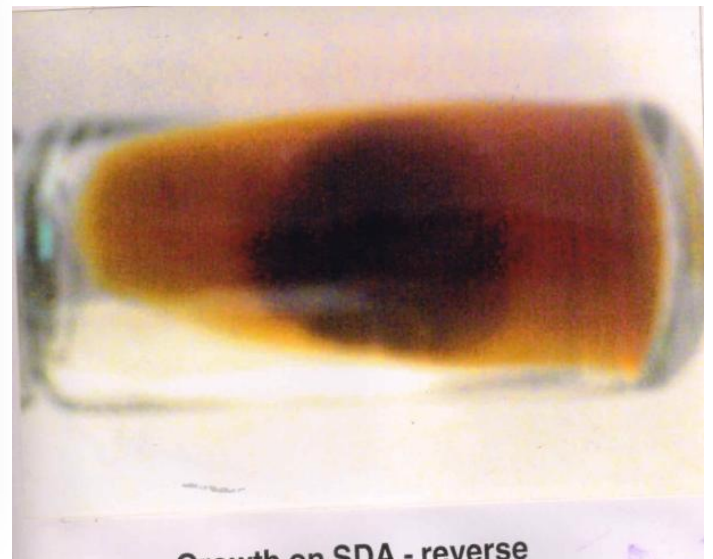

Growth on SDA - reverse

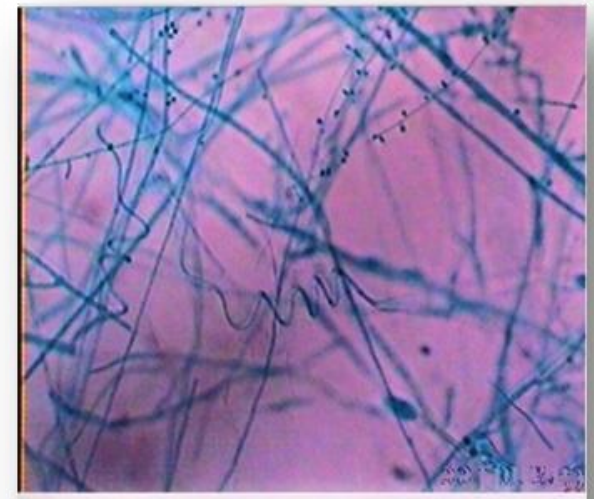

LPCB - Spiral hyphae 

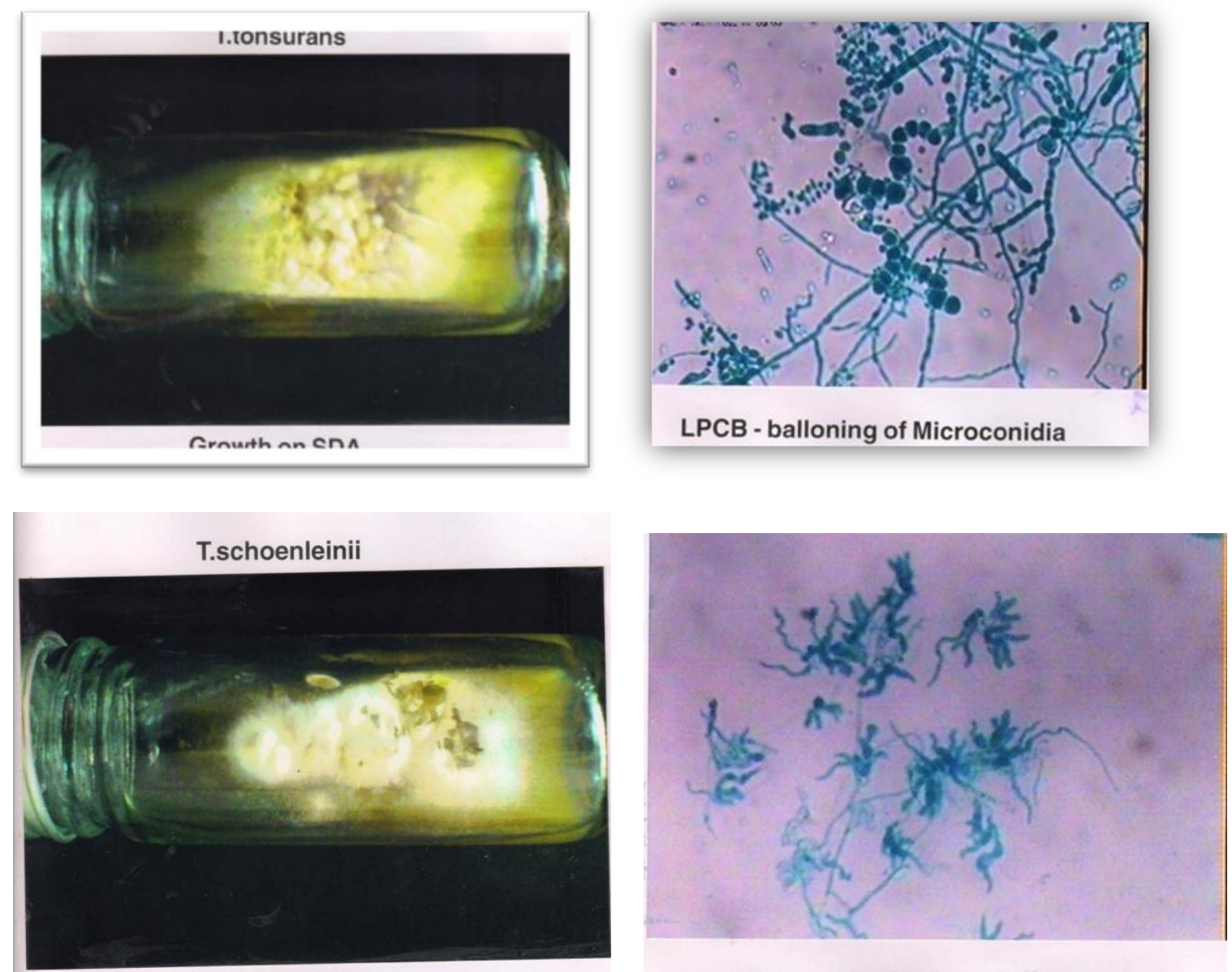

Growth on SDA

\section{LPCB - Favicchandeliers}

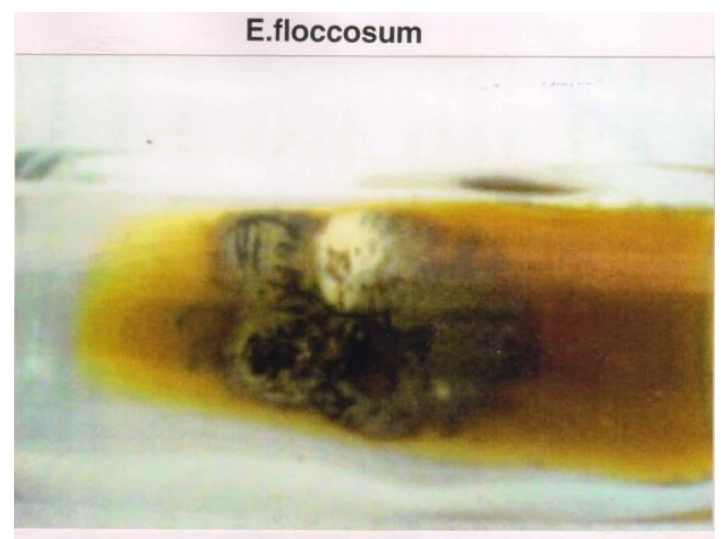

Growth on SDA

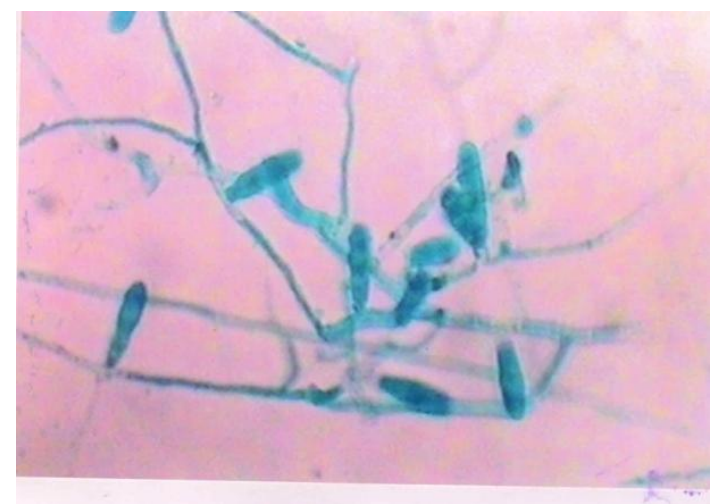

LPCB - Macroconidia

Among all the clinical types Tinea corporis was the predominanat one 55(44\%) followed by $T$. corporis with $T$. cruris $30(24.8 \%)$. This finding is similar to the study conducted by Poluri et al., 2015. The least incidence was found to be of $T$. pedis $(0.8 \%)$, T. mannum (1.6\%) and T. barbae 
using $20 \% \mathrm{KOH}$ mount which later on confirmed by culture using SDA with actidione as shown in Table 6.The correlation of direct microscopy and culture positive was seen in $85(68 \%)$ of the 125 cases. Direct microscopy was positive in $111(88.8 \%)$ cases and culture was positive in $94(75.2 \%)$. This shows that direct microscopy by $\mathrm{KOH}$ mount is useful screening technique in the laboratory diagnosis of dermatophytosis. $\mathrm{KOH}$ positive and culture negative were $20(16 \%)$. $\mathrm{KOH}$ negative and culture negative were $8(6.4 \%)$. This study is in accordance with the study of Gupta et al., 2014; Doddamani et al., 2013, who reported $55 \%$ and $65 \% \mathrm{KOH}$ positivity and $46 \%$ and $39 \%$ culture positivity.

In the present study, T. rubrum 32 (37.64\%) was the most common species isolated, followed by T.mentagrophytes 26(30.58\%), Table 7. This was in correlation with other studies conducted by Mohanty et al., 1998; Singh et al., 2003; Peerapur et al., 2004 and Poluri et al., 2015. Other species isolated in our study was $T$. violaceum, $T$. tonsurans, $\mathrm{T}$. verrucossum $(7.05 \%)$ each. E. floccosum 4(4.73\%), M. audouinii 3(3.53\%) and T. schoenleinii $2(2.35 \%)$.

The correlation between species isolated and the clinical types was shown in the Table 8. In our study all the three genera of dermatophytes, that is Trichophyton, Epidermophyton and Microsporum have been isolated as the causative agents. $T$. rubrum (37.64\%) was the commonest causative agent in majority of clinical types followed by T.mentagrophytes (30.58\%) which is similar to other studies conducted by Peerpur et al., 2004; Doddamani et al., 2013. In Tinea capitis 5 (4\%) cases, we have isolated $T$. violaceum(3), T. tonsurans (1) and $T$. verrucosum (1) which is similar to the findings of Peerpur et al., 2004; Poluri et al., 2015 study.
Our study was compared with reports of dermatophytosis in South and Northern parts of India, (Table 9). Studies showed that $T$. corporis is the most common clinical type and $T$. rubrum followed by $T$. mentagrophyte is the most common etiological agent in most of the studies, except in study conducted by Gupta et al., and Reena Ray Ghosh et al., 2014 in their study showed that $T$. unguium is the common clinical type but $T$. rubrum and $T$. verrucosum are the commonest causative agents, which is in contrast to our study.

In conclusion, dermatophytosis is a common public health problem affecting all age groups in our area and usually seek medical advice for cosmetic reasons. The present study reveals that $T$. capitis is the commonest clinical type in children and $T$. corporis in adults. Males were more frequently affected than females. The commonest isolates were $T$. rubrum followed by T.mentagrophytes. Dermatophytosis diagnosis based on clinical findings confirmed by the wet mount using $\mathrm{KOH}$ is useful screening technique followed by gold standard culture using SDA with actidione is best method for diagnosis and appropriate treatment of the patient. Use of nonocclusive absorbent cotton garments and good hygiene prevent ring worm infection.

Funding: No funding source

Conflict of interest: None declared

\section{Acknowledgements}

I sincerely thank our former Professor and HOD of Microbiology, Dr. K. Sree Rama Rao, M.D. Dr. S. Subbarayuda, M.D. Dr. S. Lalitha, M.D and Dr. M. Raja Rajeswari, M.D, for their valuable guidance without which the study could not have been completed. I thank Dr T. Surya Prakash Rao, 
M.D. D.D. Professor \& HOD of Department of Dermatology for his help in procuring the samples. I also sincerely thank all the teaching and nonteaching staff of Department of Microbiology, NRI Medical College \& $\mathrm{GH}$ for their support.

\section{References}

Bose, et al. 2013. Clinico-mycological profiles of Dermatophytosis in a tertiary care rural Hospital, IJBAR, 04(01): 31-34.

Damle, A.S., Fule, R.P. et al. 1981. Mycology of cutaneous fungal infections in Ambajogai, a rural area, Indian J. Dermatol. Venereol. Leprol., 47(5): 266-268.

Emmons, C.W., Binford, C.H., Utz, J.P., Kwonchung, K.J. 1977. Medical Mycology. $3^{\text {rd }}$ edition. Chapter 10 , Dermatophytosis. (Lea and Febriger, Philadelphia ), P.117-67.

Emmons, C.W. 1934. Dermatophytes; natural grouping based on the form of the spores and accessory organs. Arch. Dermatol. Syphilol., 30: 337362.

Forbes, B.A., Sahm, D.F., Weissfeld. 2002. As (editors). Laboratory Methods in Basic Mycology, Chapter 53, In :Bailey and Scott's Diagnostic Microbiology, $11^{\text {th }}$ Edn. Mosby: st. Louis, P.711-97.

Gupta, C.M., et al. 2014. Current trends of clinicomycological profile of dermatophytosis in Central India, $J D M S$, vol.13, issue 10, pp 23-26.

Koneman, E.W., Allen, S.D., Janda, W.M., Schreckenberber, P.C. Win, W.C. 1997. Color Atlas and Textbook of Diagnostic Microbiology. $5^{\text {th }}$ ed. Philadelphia: JB Lippincott.

Kanwar, A.J., et al. 2001. Superficial fungal infections. In; Valia AR, editors. IADVL textbook and atlas of dermatology $2^{\text {nd }}$ ed. Mumbai: Bhalani Publishing House; 2001, p215-58.

Mathur, M. et al. 2012. Epizoonosis of Dermatophytosis: A ClinicoMycological study of dermatophytic infections in Central Nepal. Kathmandu Univ. Med. J., 37(1): 303.

Mohanty, J.C., et al. 1998. Incidence of dermatophytosis in Orissa. Indian J. Med. Microbiol., 16: 78-80.

Poluri, et al. 2015. ClinicoMycological study of Dermatophytosis in South India, J. Lab. physicians, Vol7/issue2, 84-89.

Philpot, C.M. 1997. Some aspects on the epidemiology of tinea. Mycopathologia, 3: 62.

Peerapur, B.V., et al. 2004. Clinicomycological study of dermatophytosis in Bijapur. Indian J. Med. Microbiol., 22: 273-4.

Doddamani, P.V. et al. 2013. Isolation, Identification and Prevelance of Dermatophytes in Tertiary Care Hospital in Gulbarga District. People's J. Scientific Res., Vol.6(2), p 10-13.

Ramraj, V., et al. 2016. Incidence and prevalence of dermatophytosis in and around Chennai, Tamilnadu, India. Int. J. Res. Med. Sci., Vol 4, Issue 3, 695-700.

Reena Roy Ghosh, et al. 2014. Clinicomycological profile of dermatophytosis in a Tertiary care Hospital in West Bengal -an Indian Scenario. IJCMAS, Vol 3, Number 9 pp 655-666.

Ranganathan, S. et al. 1995. Effect of socioeconomic status on the prevalence of dermatophytosis in Madras, Indian J. Dermatol. Venreol. Leprol., 61(1): 16-8. 
Singh, S., Beena, P.M. 2003. Profile of dermatophyte infections in Baroda. Indian J. Dermatol. Venereol. Leprol., 69: 281-3.

Singh, U.K., Nath, P.1981. Fungal flora in the superficial infections of the skin and nails at Lucknow. Indian $J$. Pathol. Microbiol., 24: 189-193.
Sudha, M. et al. 2016. Prevalence of Dermatophytosis in patients in a Tertiary Care Centre, Int. J. Contemporary Med. Res., Vol 3/ issue 8 p2399-2401.

Weitzman, I., Summerbell, R.C. 1995. The dermatophytes. Clin. Microbiol. Rev., 8(2): 240-259.

\section{How to cite this article:}

Uma Penmetcha, Ramesh Babu Myneni, Padmaja Yarlagadda and Susmitha Simgamsetty. 2016. A Study of Prevalence of Dermatophytosis in and around Guntur District, Andhra Pradesh, South India. Int.J.Curr.Microbiol.App.Sci. 5(9): 702-717. doi: http://dx.doi.org/10.20546/ijcmas.2016.509.081 